suitable ceremonial by another whenever it died. This decision has, also, its scientific aspect, on account of the proximity of the Norman Lockyer Observatory to Thorn Farm, where (but for the action of Dr. Cornish) it would have been possible to erect some six hundred houses under the local town planning scheme. It is well known that the work of Greenwich Observatory is badly hampered by smoke and glare from the surrounding district. The erection of six hundred houses in the vicinity of the Norman Lockyer Observatory might have been the first step towards a similar interference with the work of this observatory, and it is a matter of satisfaction that this annoyance has been at least postponed during the lifetime of Dr. Cornish.

\section{Earliest Man}

Mr. J. REID MoIr, with an admirable sense of propriety, took as the text of his Huxley Memorial Lecture for 1939 before the Imperial College of Science and Technology on May 4 certain questions posed by T. H. Huxley in his famous book "Man's Place in Nature". There Huxley asked : "Where, then, must we look for primeval man ? Was the oldest Homo sapiens Pliocene or Miocene, or yet more ancient ?" Readers of Mr. Reid Moir's lecture in its published form ("The Earliest Men". By J. Reid Moir. London : Macmillan and Co., Ltd. Pp. 32. 1s. net) will appreciate the choice as lecturer on this occasion of an investigator of man's origins, who through his association with Edwin Ray Lankester is directly linked with Huxley, and also by his own researches has contributed so much of the material which must be taken into account by everyone who ponders the problems thus formulated by Huxley so long ago. The evidence of man's skeletal remains, as well as of his artefacts, which has been laboriously collected, pieced together and interpreted by numerous investigators since Huxley's day, ably summarized and surveyed by Mr. Reid Moir, may seem formidable enough in its detailed mass, but it is still far from offering a final solution of man's origins. Nevertheless it makes it possible to adumbrate a generalized formula, from which it may be that a concrete answer eventually will emorge. If in the meantime Mr. Reid Moir's technological and æsthetic arguments may seem a little overweighted in the period and degree of man's development they demand, and his credence in Miocene man a thought too readily conceded, none can deny that in his life work he has abundantly shown faith in that of which his powers of observation and reason have convinced him-the belief in the power of truth ultimately to prevail, which Huxley urged upon the youth of his time.

\section{Verulamium Museum}

The new Verulamium Museum at St. Albans, which has been erected by the Corporation at a cost of $£ 8,000$, was declared open by the Earl of Harewood on May 8. The purpose of the Museum is to house the finds from the excavation by Dr. R. E. Mortimer Wheeler and the late Mrs. Wheeler between 1930 and 1934 of the Roman city of Verulamium and the pre-
Roman Belgic city in Prae Wood. A tablet in the entrance hall commemorates Mrs. Wheeler's part in the excavation. The museum building, of which $\mathrm{Mr}$. F. Newton is the architect, and Mr. Philip Corder will act as curator, contains in addition to offices and laboratories, a museum hall $75 \mathrm{ft}$. long, in which are displayed a selection of the finest and most typical specimens from the two sites, grouped in an arrangement which will most readily convey their significance to the visitor. The large mass of material still under examination at the Institute of Archæology in London will eventually be stored in the Verulamium Museum, and though not displayed, will be available for students' reference. Three of the finest of the mosaic pavements discovered at Verulamium, including the square pavement displaying the remarkable head of a sea god, and the striking semi-circular scallop-pattern pavement of about A.D. 130-150, are shown on the end-wall, facing the visitor on entering. On the left of the entrance are the wall-cases containing the Belgic pottery, both imported and home-made, from the pre-Roman site of Prae Wood, ranging in date from about A.D. 10-40. The remaining cases are given up to exhibits from Verulamium. The material culture of the inhabitants of the Roman site is exhibited in the long series of burial groups, among which not the least interesting relic is a denarius of Augustus, which was converted into a Mithraic token some two centuries after its issue. A large model of the important south-eastern, or London, gate is also shown.

\section{Preservation of Fauna and Flora}

IN an address entitled "The Dawn of a Geological Period" delivered at the London School of Hygiene and Tropical Medicine on May 4 for the University of London, under an arrangement for an exchange of lectures with the Universities of Belgium, Prof. V. van Straelen, director of the Royal Natural History Museum of Brussels, discussed the inroads made on the fauna of the world by the activities of man and especially by the exploitation of Central Africa. He pointed out the fact, which is usually entirely neglected if not always unrealized, that not only are the larger mammals threatened with extinction by the advance of settled areas in tropical Colonies, but also that the felling of rain forests, by exposing the soil to the direct attack of sunlight, renders it impossible to reafforest such lands, and by completely altering all the micro climatic conditions, necessarily causes the destruction of all smaller plants and animals, whether they live above, upon or in the soil. In the light of his own great experience of such conditions, and of others the ultimate effects of which are similar, Prof. van Straelen showed that the changes of fauna and flora which are now occurring are in magnitude analogous to those which characterize the geological periods, and thus justified his title.

\section{Cosmic Rays}

Prof. P. M. S. BlacketT took "Cosmic Rays" as the subject of the thirtieth Kelvin Lecture which he delivered before the Institution of Electrical En- 